\title{
KO IMA PRAVO DA IGRA? OMETENOST I ESTETIKA EGZISTENCIJE ${ }^{1}$
}

Sažetak: Članak istražuje odnos između osoba s ometenošću i pozorišta polazeći od rada Udruženja Per-Art. U prvom delu rada autor naglašava da moderno sazrevanje društvene solidarnosti s osobama s ometenošću nije imalo za rezultat njihovu veću, nego manju prisutnost u likovnim umetnostima. Nakon pokazivanja da se prisustvo osoba s ometenošću na platnu vekovima svodilo na mehanizam zahvaljujući kojem se osnaživala svakidašnja svest o »zajedničkom«, i uvežbavala se da s lakoćom odbacuje sve što odstupa od društveno usvojenih normi, autor analizira posebnosti inkluzivnih gestova na savremenoj pozornišnoj sceni. Za razliku od uvođenja pojedinačnih likova s ometenošću u konvencionalne predstave, autor ističe da svakidašnji režim brige osobe s ometenošću prepoznaje kao objekte o kojima se moraju pobrinuti drugi, dok im uslovi grupnog umetničkog rada omogućavaju da iskroje vlastiti lik tako da se, što je najvažnije, ne oslanjaju na predstave i očekivanja drugih. U drugom delu rada autor sučeljava Fukoov pojam estetika egzistencije sa pozorišnim radom osoba s ometenošću. Grupno pojavljivanje takvih osoba na sceni omogućava moralnu konverziju zahvaljujući tome što se značenja scenskog pokreta preobražavaju u samosvojni moralni zahtev. Susret s drugošću ometenih za publiku postaje sinonim za iskorak iz egoističnog traženja sebe u drugima, a za same aktere na sceni označava šansu za nadmašivanje društvene separacije.

Ključne reči: estetika, egzistencija, pozorište, ometenost

\section{Drama prisustva i odsustva: umetnički prikaz ometenosti}

Sliku ljudskog tela u umetnostima ne treba razdvajati od normi koje regulišu i vladaju njegovom materijalizacijom (van Rijn, 2011: 228). Vizuelizacija tela, umetničko insceniranje telesnosti nema tek edukativnu pozadinu čija svrha je da nam približi najrazličitije telesne oblike i da time omogući da nam ništa ljudsko ne bude strano. $\mathrm{S}$ one strane pedagogije i estetike, prikazi tela su po pravilu i medijum samopotvrđivanja postojećih međuljudskih ograda. U pozadini vidljivih

\footnotetext{
Dragan Prole, e mail adresa: proledragan@ff.uns.ac.rs, ovaj rad nastao je zahvaljujući podršci Republičkog ministarstva prosvete, nauke i tehnološkog razvoja tokom rada na projektu 179007.
} 
likovnih uobličenja ljudskog tela vekovima se vodi nevidljiva borba koja se začinje u favorizovanju izvesnih vidova telesnosti. Dakako, kao svoj korelat ono uvek ima i odbacivanje, odnosno marginalizovanje nekih drugih vidova. Otuda je jasno da poželjni, ujedno i idealizovani reprezenti telesnosti koji se mogu podičiti planetarnom popularnošću ne predstavljaju pozni istorijski proizvod. U njima ne treba prepoznavati učinak sveprisutnosti savremenih audio-vizuelnih medija. Oni su tek savremeni baštinici dugovečne istorije prikazivanja ljudskog tela, čija svrha je bila da polarizuje i da na prepoznatljiv način razdvoji društveno poželjno od nepoželjnog. Nasuprot očekivanom, kolektivno osvedočenje u tu polarizaciju nema za cilj fragmentiranje i stvaranje podela u zajednici. Naprotiv, funkcija likovnih prikaza tela sastoji se u doprinosu stabilizaciji i utvrđivanju onoga što se obično zove grupni identitet. Učestalost i kontekst prisustva ili odsustva ometenosti na umetničkoj sceni u direktnoj je vezi sa društvenom samosvešću o normama, o mehanizmima društvene samoregulacije. Pri tom ipak ne treba podlegati zavodljivoj sugestiji da je stepen prisustva osoba sa ometenošću direktno srazmeran liberalnijem poretku i manjem nivou isključenosti ometenih iz zajednice.

Bogatstvo i dramatičnost evropske istorije nužno su se obelodanili i na polju odnosa između umetnosti i prikazivanja različitih ljudskih nedostataka. Već šturi pregled te istorije donosi uznemirujuće otkriće da prikazi osoba sa ometenošću nemaju svoje prepoznatljivo i dovoljno vidljivo mesto kako u drevnim i arhaičnim počecima umetničkog izražavanja, tako i u aktuelnom trenutku evropske umetnosti, u kojem nipošto ne manjkaju akteri na sceni koji se samouvereno razmeću svojom emancipovanom samosvešću. Ipak, neočekivana srodnost savremenog estetskog ukusa sa najstarijim umetničkim tvorevinama sastoji se u marginalizaciji ometenosti i njenom potiskivanju iz središnjih medijuma koji posreduju vizuelnu kulturu.

Pođemo li unatrag, shvatićemo da je uzajamno delovanje umetnosti i društva tokom dvadesetog veka otkazalo gostoprimstvo umetničkom prikazivanju osoba sa ometenošću. Poredimo li savremenost sa minulim vremenima, uočićemo drastično umanjenje umetničke pažnje. Umesto da zajedno sa sazrevanjem društvene solidarnosti i odgovornosti prema osobama s ometenošću, jača i njihova vidljivost u umetničkim polju, dešava se obratan proces. Sve manje prisustvo osoba s ometenošću u vizuelnoj kulturi predstavlja rezultat promenjene društvene percepcije ometenosti. Ipak, iza njega nije stajao povećani stepen ravnodušnosti, nego značajno razvijenija svest o rasprostranjenoj manipulaciji i neprihvatljivoj stigmatizaciji ometenosti. Naime, $u$ ranim vekovima modernosti prikazi (najčešće likovni) ometenosti su stupali na dnevni red kada god je trebalo pojačati pažnju posmatrača, ili uverljivo ukazati na nešto čudesno i neobično. Bilo da je reč o prikazu »patuljka« tik pored maloletne princeze obasjane svetlom na slavnom Velaskezovom platnu, o hrišćanskom motivu »mudre lude « koja je tu da posrami gorde ovozemaljske mudrace, o trenucima ludičke karnevalske sabotaže i preokretanja uvreženog poretka, ili o nekom drugom nesvakidašnjem motivu, svuda se ometenost stavljala u funkciju oneobičavanja. To najpre znači da ona nije 
bila umetnički evocirana zbog nje same. Što znači da stepen njenog prisustva na slikarskim platnima nije bio srazmeran pažnji koja joj je pripisivana. Naprotiv, interes za prikaz ometenosti bio je direk tno vezan za njen dragoceni kapacitet da pojača utisak kod posmatrača. Ona prosto nije bila prikazivana usled empatije i potrebe za društvenom solidarnošću nego zato što je stvarala kontrast, odnosno snažno je doprinosila stvaranju efekta začudnosti.

Za razliku od modernih početaka, u novija vremena više nije bila samorazumljiva proizvoljna manipulacija ometenošću radi pojačavanja umetničkih efekata. Susret s ometenošću je postepeno prestajao da izaziva infantilni smeh i zluradost kada je nakon više milenijuma napokon sazrela svest da bi ismevanje $i$ podrugivanje trebalo da budu zamenjeni brigom i empatijom zajednice. Paralelno sa rastućom institucionalnom brigom o ometenima, u umetnostima su postepeno postajali sve ređi prikazi čije namere su bile bliske preostalim recidivima kolektivnih predrasuda. Međutim, za ono što biva istisnuto iz kolektivnog imaginarijuma, iz struktura vizuelne kulture zajednice, obično se kaže da i ne postoji. Otuda nam pogled ka novijoj istoriji umetničkog prikazivanja ometenosti svedoči da se iza nove saosećajnosti, brige i empatije krije sistematski vid institucionalne izolacije i isključivanja ometenih iz predstava zajednice o samoj sebi. Savremene studije listom pokazuju da čak ni uspešni primeri i pozitivna praksa inkluzije ne ukida savremene društvene mehanizme selekcije i sankcije, te da »rasprave o inkluziji najčešće ostaju samosvojne i nedodirnute kritičkim refleksijama o društvenim mehanizmima razgraničenja« (Becker, 2015: 13). Doista, kakav lik društvenosti se krije iza novovrsne pažnje prema ometenima čija javna promocija se prečesto svodi na dokazivanje vlastite moralne korektnosti? I, što je još važnije, kakvi likovi ljudskosti se pomaljaju u interesu za ometenost radi nje same?

\section{Fascinacija antropološkim deficitima}

U savremenim društvima biti ometen ujedno znači i biti ometan. Susret sa nekim nasleđenim ili stečenim hendikepom nikada se ne završava u ravni svih onih segmenata životnog sveta koji im bivaju u potpunosti uskraćeni, ili tek delimično pristupačni. Upućenost na posebni tretman unutar obrazovnog sistema, izostanak prostora i sluha na tržištu rada, kao i značajno veći stepen neophodne ljudske brige i podrške predstavljaju okvire života koji je daleko složeniji od uobičajenog. Delikatna egzistencija ometenih ima dvostruko poreklo. Pored suočavanja s konkretnim tegobama oni su itekako izloženi društvenoj konstrukciji ometenosti. Ona se prevashodno ogleda u retorici nedostatka koja se ne zadržava na nekim karakternim i fizičkim osobenostima, nego se po automatizmu totalizuje.

Iz perspektive onih koji ga nemaju, nedostatak lako prianja uz celinu ličnosti. Sa gotovo sudbinskom nužnošću on se priširuje i pripisuje svim segmentima ljudskosti. Otuda se za osobe s ometenošću može reći da predstavljaju živo svedočanstvo sklonosti savremenog doba da se posebnost s lakoćom transformiše 
u totalitet. Čini se da drevna logika pars pro toto postaje osnovno obeležje našeg opažanja i ukupnog doživljaja ometenosti. Kada to tvrdimo prevashodno mislimo da se naš doživljaj osobe s ometenošću po pravilu drastično sužava na iskustvo te ometenosti. Kao da susret s nedostatkom ujedno predstavlja i svojevrsnu fascinaciju antropološkim deficitima. Poput svake fascinacije, i ovaj put je zapravo reč o izvesnom vidu zaslepljenosti, zahvaljujući kojem se neka osoba u potpunosti podvodi pod njen nedostatak. Nedostatak tako postaje oznaka celine ličnosti, pouzdana uporišna tačka na osnovu koje negativnim prefiksima određujemo sve zamislive životne odnose te osobe. Prema njoj samoj, prema drugima, prema zajednici. Individualna istorija osobe se u slučaju ometenosti uvek ukršta sa istorijom društva u kojem ona živi. Govor o ometenosti utoliko je indirektan govor društva o samom sebi.

Prema preovlađujućem mišljenju biti ometen znači biti nesabran, nerazborit, emotivno nezreo, nedovoljno inteligentan, nesposoban za fizički rad. Biti ometen otuda ne podrazumeva tek osuđenost na tegobno svakidašnje susretanje sa konkretnim prirodnim ili duhovnim nedostatkom. Naprotiv, to isto tako znači i biti ometan. Susret sa sobom kod osoba sa bilo kojim vidom ometenosti podrazumeva i suočavanje sa društvenom konstrukcijom nedostatka. Predstavljati neki nedostatak u očima drugih iznad svega znači govoriti drugačijim jezikom, odnosno ne deliti zajednički jezik. Utoliko je moguće ustanoviti nesvakidašnju srodnost između osoba s ometenošću i stranaca koji ulažu poseban napor da se približe onome što je nama samorazumljivo i lako. Naime, oni koji ne govore našim maternjim jezikom obično postaju sve simpatičniji u meri u kojoj im pođe za rukom da ga savladaju, te da posredstvom nama bliskih, kolokvijalnih izraza saopšte drugovrsna kulturna iskustva i sadržaje.

U sličnom maniru i od osoba sa ometenošću očekujemo da svoju ometenost žive tako će biti spremne da nam se obrate našim svakidašnjim jezikom. Štaviše, i mi ćemo biti raspoloženi da ih saslušamo ukoliko im pođe za rukom da artikulišu nešto što nas podseća na nas same. Bićemo čak i velikodušni u svojim pohvalama, darivaćemo ih nesebično epitetima upadljivog napretka i nadmašivanja ličnih nedostataka, samo pod uslovom da nam ne svedoče o sebi, nego da na neki način posreduju osećanja i razmišljanja koja smo i sami već osetili ili promislili.

Otuda se iskustvo ometenosti ne ograničava tek na institucionalnu segregaciju, na boravak u drugačijem režimu školovanja i odrastanja, odnosno na potpunu skrajnutost na tržištu rada. Naprotiv, ometenost je možda još i više karakteristična po ometanosti, po svojevrsnoj društvenoj ućutkanosti. Naime, ometenost nam je obično podnošljiva tek ukoliko nam se obraća iz horizonta očekivanja koje unapred isključuje bilo kakvo skretanje ili devijaciju. Ometenost je dobrodošla tek kao doprinost režimu istog, kao potvrda normiranog, ustanovljenog i samorazumljivog. Kao što nevešte jezičke konstrukcije stranaca sa svim nezamislivim kombinacijama nepravilno izgovorenih reči po pravilu izazivaju samo kratkotrajnu pažnju i uzgredni smeh, tako i svaka nevešta devijacija ometenih, svako iznenadno iskliznuće izvan horizonta očekivanja izaziva negodovanje i nelagodu. 
Pošto se naša reakcija na nepravilno izgovorenu reč svodi na podsećanje govornika na njen pravilan izgovor, smatramo sasvim prikladnim i ignorisanje uočene devijacije, odnosno njeno upućivanje na »normalan« kolosek i očekivani način ponašanja i reagovanja. Potvrda važenja zajedničkog jezika u slučaju susreta s ometenošću podrazumeva rutinsko isključenje i marginalizaciju svakog oblika devijacije. Ako svakidašnja svest o »zajedničkom« s lakoćom odbacuje sve što odstupa od društveno usvojenih normi, možemo postaviti pitanje da li takva odstupanja izazivaju drugačije reakcije kada se s njima suočimo u nesvakidašnjem ambijentu, kada ih iskusimo u horizontu umetnosti, odnosno estetskog iskustva?

\section{Manipulacija ometenošću i proizvodnja začudnosti}

Efekat začudnosti, u kojem se još od Aristotela prepoznaje osobenost dejstva umetničkih gestova, biva naročito uverljiv kada se posebnost nekog narativa uspešno inscenira iz perspektive subjektivnosti koja mu je heterogena. Sledstveno tome, i dramski doživljaj biva nesumljivo pojačan kada neku složenu ulogu poverimo osobi s ometenošću. Kada je doživimo usred Hamleta, Vilhelma Tela ili Godoa, mi smo prinuđeni da odustanemo od svoje rutinske sklonosti da niveliramo ometenost ili da ignorišemo razliku koja ona obično podrazumeva. Nesvakidašnji momenti dramskog lika bivaju dodatno pojačani, jer mi intenzivnije reagujemo na otelovljeno prevođenje razlike, nego na razliku prikazanu standardnim pozorišnim sredstvima, oslonjenim tek na inscenaciju karaktera posredstvom radnje. Kada se na sceni pojavi osoba s ometenošću, razlika karaktera ujedno postaje $i$ telesna razlika, junak s ometenošću snažnije svedoči o sukobu, o nepremostivom jazu koji postoji između njega i ostalih likova na sceni. Međutim, čak i u takvoj situaciji ometenost je tu da nam govori o nama, a ne o samoj sebi.

Štaviše, kada predstavlja usamljenu pojavu na sceni, dramski lik s ometenošću dodatno svedoči o drami nevidljivih barijera u kojoj je osuđen na ulogu nemog posmatrača. Uspeh takvih predstava kod publike one mogu da zahvale kapacitetima umetničkog dela da verno iznese postojeću materijalnost zajednice. Snažan utisak koji one proizvode na retkim savremenim pozorišnim scenama koje su se odvažile da u svoje reprezentativne ansamble uvrste i poneku osobu s ometenošću otuda se sastoji u inverziji, prema kojoj ono drugo govori za nas $i$ o nama.

Nadalje, kao usamljeni član uobičajenog ansambla osoba s ometenošću nehotice participira u iskustvu »normalizacije«. Ono podrazumeva pristup čija se empatija svodi na dopuštanje da i osobe s ometenošću mogu nešto da odglume, ali u isti mah zahteva da se o toj glumi sudi prema imanentnim umetničkim kriterijumima koji su isti za sve. Rezultat takvog pristupa istovetan je surovom pragmatizmu, jer od osoba s ometenošću traži da dokažu da mogu da se hvataju u koštac $s$ visokim zahtevima scene. Ukoliko te zahteve ispunjavaju, daje im se legitimacija da su dostojni publike, dok im se u protivnom odriče pravo na prisustvo na sceni, jer publika tobože ne dolazi u pozorište da bi trošila vreme za milosrđe gde mu mesto nije. U konačnom, gestove osoba s ometenošću na pozornici možemo 
doživeti kao puku glumu, kao nešto što predstavlja sastavni i samorazumljivi deo pozorišta. Takva vrsta ometenosti se u tom slučaju više ne ispostavlja kao stvarna, nego tek kao glumljena.

Uspešnim postavljanjem na scenu, ometenost gubi svoje realno lice, jer tamo ona zapravo traje koliko i predstava, a nakon predstave glumci s ometenošću gube svoju posebnost i postaju isti kao i mi. Nije otuda ni malo slučajno da se u poslednje vreme vrhunske glumačke nagrade dodeljuju glumcima koji su ostvarili bravure igrajući likove osoba s ometenošću. U pozadini neosporno velikog glumačkog umeća krije se i nešto, što s pozorištem nema nikakve veze. Naime, svojim uspešnim postignućem glumci i glumice zapravo predstavljaju živo otelovljenje društvenog sna o normalizaciji. Nakon vešto estetizovane i odglumljene ometenosti, oni nam se obraćaju u punom sjaju nasmejanih, ostvarenih, zadovoljnih i iznad svega zdravih osoba. Ometenost na filmu je utoliko tek ružan san iz kojeg se izlazi na društvenoj javi. Na osnovu tog srećnog obrata iz sfere estetizovanog u sferu realnog razotkriva se mehanizam koji podstiče savremena insceniranja ometenosti. Možemo da uočimo da spremnost velikih producentskih kuća da središnju pažnju na filmu ili na pozornici posvete upravo nekoj osobi s ometenošću ima za cilj da provocira srećan ishod, prema kojem nam se osoba koja je glumila ometenost prikazuje kao lišena bilo kakvih tegoba, upravo kao jedna od nas. Stvari se, dakako, značajno teže kreću u obratnom pravcu. S kakvim utiskom publike bismo mogli da računamo kada bi se nakon predstave ispostavilo da lik koji se poklanja publici zapravo krije osobu s ometenošću? Štaviše, da li bi jednaka mera glumačke veštine bila priznata i osobi čije se majstorstvo svodi na uspešno maskiranje vlastite ometenosti?

\section{Umetnički susret sa sobom}

Kako god s tim da stoji, odnos prema osobama s ometenošću se čak i na pozornici stabilno održava u okvirima režima istog. Međutim, »odnos između Istog i Drugog se ne svodi uvek na svest Istog o Drugom, pa čak ni na Objavu Drugog Istom« (Levinas, 1968: XVI). Ukoliko bismo za ovaj credo najznačajnijeg dela francuskog fenomenologa pokušali da pronađemo ekvivalent u savremenoj umetničkoj produkciji koja se bavi osobama s ometenošću s pravom bismo mogli da ukažemo na rad novosadskog Udruženja Per Art. Posebnost rada ovog udruženja krije se u nastojanju da nam se osobe sa ometenošću obrate na način koji se ne uklapa u naša konvencionalna očekivanja. Štaviše, one se time značajno približavaju izvornom smislu obraćanja drugoj osobi. Oslovljavajući nas sa željom da nam ne predstave sebe onako kako je »poželjno« i kako unapred očekujemo, osobe s ometenošću nas sa scene podsećaju na izvornost međuljudske komunikacije.

Za razliku od pozivanja, koje je nam je zajedničko sa mnogim životinjama, čoveku je suštinski svojstveno oslovljavanje, »a ono se temelji na stavljanju i na priznanju samostalne drugosti drugog « (Buber, 1962: 420). Shvatimo li naglasan Buberovog pojma oslovljavanja, postaće nam jasno da ono uopšte nije toliko često 
koliko obično mislimo. Događaj oslovljavanja nije svodiv na puko obraćanje. Oslovljavanje iziskuje da budu ispunjene posebne pretpostavke, ono traži susret s drugošću za koji ne važi naša uobičajena sklonost da tu drugost suspendujemo $i$ niveliramo. Umesto da nam govore o nama i da podražavaju sadržaje koji se uklapaju u naša očekivanja, članovi grupe Per Art radije svedoče o sebi. Individualna avantura, u koju se upušta svaki pripadnik ove grupe oslovljavajući prisutne u publici, ipak ne implicira ukidanje slutnje o kolektivnoj sudbini svih onih koji pate od izvesnog vida ometenosti.

U jednom intervjuu, inspirator i rukovodilac udruženja Per-Art Saša Asentić je sažeto izneo programska načela rada koja insistiraju na dugoročnoj posvećenosti istoj grupi, bez koje ne bi bilo zamislivo da se svakom pojedincu omogući da otkrije šta sve može, da se suoči s neslućenim mogućnostima. Nije potrebno posebno da napomenemo da bez umetničkog rada osobe s ometenošću ne bi ni pomislile da takvim mogućnostima raspolažu. Odnos aktivista udruženja i osoba s ometenošću uspešno je izmakao zamkama hijerarhije, tutorstva i bilo kakvog oblika projektovanja vlastitog stava. Osobama s ometenošću se na taj način omogućava da postanu nešto drugo od onoga što obično predstavljaju, a da taj proces ne predstavlja bilo kakvu mimikriju, nego svojevrsno samootkrivanje. Uslovi sa kojima se članovi grupe suočavaju tokom umetničkog rada sasvim su drugačiji od uobičajenih, tako da i njihovo suočavanje sa samim sobom dobija značajno drugačije predznake. Ključna razlika mogla bi se uočiti u konfiguraciji brige, kao neprevaziđene osnove ljudskog samoodnosa.

Zajednički umetnički rad ovde je rukovođen idejom da briga ne predstavlja nikakvu vrstu proizvodnje, manipulacije ili objektiviranja, nego prosto »bivstvovanje zajedno sa« (Bass, 2006: 39). Naglasak ideje da se briga može sastojati u zajedničkom umetničkom radu ovde ne podrazumeva tek efikasnu obuku i osposobljavanje za uspešno udovoljavanje visokim zahtevima scene, već implicira proces koji iziskuje značajno vreme. Tek pod uslovom toga zajedničkog vremena dolazi do izražaja posebni oblik brige čiji smisao je oslobađanje osobe s ometenošću za ono što joj zajednica obično odriče, a tiče se presudne životne mogućnosti da se »pobrine za sebe«. Sloboda za vlastitu brigu drugo je ime za uspešno izmicanje dominaciji nametnutih društvenih atributa koji prate standardna tumačenja ometenosti. Rečju, svakidašnji režim brige osobe s ometenošću prepoznaje kao objekte o kojima se moraju pobrinuti drugi, dok im uslovi umetničkog rada omogućavaju da iskroje vlastiti lik tako da se, što je najvažnije, ne oslanjaju na predstave i očekivanja drugih. U sličnom duhu je glumac i scenarista Džon Beluso opisao svoju svakidašnjicu kao kontinuiranu teatralizaciju, kao uvek iznova ponavljano iskustvo scene u kojoj se osobe s ometenošću zatiču izvan pozorišnog konteksta. Naime, opisujući svoj ulazak u autobus u invalidskim kolicima, Kaluso rečito predstavlja tipičnu scensku situaciju, odnosno neobični performans, čiji nevoljni akter je osoba s ometenošću, a revnosnu publiku čine sličajni prolaznici. Rečju, scenska situacija za Kalusa ne označava pozorišnu posebnost, jer zapravo sačinjava njegovu svakidašnjicu: 
»Kada uđem u autobus, sve glave se okrenu i u tom trenutku je kao da sam na sceni. Osobe s ometenošću razumeju svet na drugačiji način. Onda znaš kako je to kada zure u tebe, kada te posmatraju, i u izvesnom smislu uvek izvodiš svoju ometenost«. (Straus, 2011: 128)

Nelagoda izloženosti pogledima drugih potiče iz kolektivnog signaliziranja telesne drugosti. Zureći subjekti su fascinirani ometenošću, a osobi pogođenoj njome preostaje tek da stoički odigra vlastitu drugost. Nasuprot ovome, neizrečeni program udruženja Per Art bi se sastojao u projekciji uslova zahvaljujući kojima se osobe sa ometenošću više neće neprekidno suočavati sa društvenim okolnostima u kojima im je onemogućeno da uspostave odnos sa sobom. Pri tom aktivisti ovog udruženja itekako imaju u vidu da se najteža posledica društvene konstrukcije ometenosti zapravo sastoji u lišavanju ličnog iskustva društvene potvrde i priznanja. U svakidašnjici, njih obično čeka ansambl negacija, pomoću kojeg im se neprekidno saopštava da im nešto nedostaje. Ono što im svakidašnjica ostaje dužna, sastoji se u afirmaciji njihovih mogućnosti i prepoznavanju onoga što jesu i šta mogu da budu, a što nije svodivo na lišenost i na nedostatak. Kada imamo u vidu da se savremena subjektivnost prevashodno konstituiše u relaciji s drugima, onda postaje jasno da izostanak priznanja drugih nužno znači i izostanak samosvesti, odnosno trajnu traumatizovanost ometene osobe.

Nikome, pa ni ometenima, nije dovoljna beskrajna nega i bezuslovna ljubav bližnjih ukoliko izlazak izvan roditeljskog gnezda ili najužeg prijateljskog kruga ujedno znači i unižavanje, osudu, ravnodušnost. Za tu vrstu traume moramo reći da predstavlja posledicu ometanja čiji subjekt nije pojedinac nego kolektiv čije susretanje s ometenošću podrazumeva njenu redukciju i sužavanje na svima poznati spektar negativnih atributa. Traumatizovanje ometene osobe predstavlja dosledni društveni refleks ometenosti, i nipošto ne proističe direktno iz prirode hendikepa. Sagledan iz te perspektive, umetnički rad koji je osobama s ometenošću omogućen naporima udruženja Per Art za svoj rezultat ima situacije u kojima one po prvi put doživljavaju neki vid društvenog priznanja, interesa za njih takve kakve su, pa im samim tim biva omogućeno da se po prvi put osećaju kao ličnosti.

Takav pristup ima svoju potvrdu u savremenim dijagnozama koje, poput Hajdegerove, mogućnost ostvarenja brige o sebi vide tek s one strane logike koju nameću svakidašnji aršini i merila. Ukoliko sve činimo vodeći prevashodno računa o tome kako to drugi čine, nema ništa od naše brige, pošto se svakidašnjica u tom slučaju svodi na bezlično življenje. Umesto brige i susreta sa sobom, tada je na delu oblikovanje vlastite egzistencje u skladu s rutinama koje razlog za svoja činjenja i nečinjenja vide u bezličnoj paradigmi kako se nešto radi ili ne radi. Nasuprot podleganju zamkama bezličnosti, umetnički rad sa osobama sa ometenošću stvara pretpostavke za otkrivanje ličnog, otvara prostor za individuaciju. Put kojim se kreće Per Art u radu s osobama s ometenošću u načelu ima isto polazište koje se preporučuje svakom sazrevanju, probijanju do sebe, vijugavoj putanji kojom dospevamo do vlastite ličnosti. 
U savremenim uslovima, naša briga o sebi ima etički primat $u$ odnosu na institucionalnu brigu o nama. To posebno dolazi do izražaja kod osoba sa ometenošću, jer se institucionalna briga o njima svodi na normirajuće diskurse psihologije, psihijatrije i medicine. Notorna nevolja s psihijatrijom sastoji se u tome što se ona konstituiše kao »medicina alijenacije« (Fuko, 2002: 387), što uspostavlja odnos subjekt-objekt, u kojem se objektivnost pacijenata prepoznaje $\mathrm{u}$ njihovom odstupanju od norme, u njihovoj stranosti u odnosu na dominantne društvene predstave o »normalnom «, odnosno »zdravom《, "prilagođenom《 subjektu. Njoj nasuprot, članovi Per Art intuitivno prepoznaju mehanizme segregacije posredstvom fiksiranja nepremostive razlike i odbijaju atribut stranosti, videvši u svojim kolegama različite pojedince, ali nipošto ne i strance: »Svi su različiti a među nama nije stranac« (Vladisavljević, 2014: 75).

\section{Jezik graničnih iskustava}

Nije neobično što u nastupima osoba s invaliditetom dominiraju osećanja koja prevashodno bivaju markirana jezikom graničnih iskustava. $U$ okvirima narativa koji se artikuliše sa rubnog područja, iz perspektivne isključenosti i traumatizovanosti prisustvo bola i patnje komplementarno je imaginiranju drugačijeg života. Fantazije o životu vrednom življenja po pravilu bivaju praćene naglašavanjem moguće sreće i nadom u ispunjenje zahvaljujući pažnji druge osobe, odnosno verom u spas posredstvom ostvarene i uzvraćene ljubavi. Nesvakidašnje je prepletanje vlastitog i drugog. Kao da je bol drugoga moguće učiniti vlastitim, a da se tuđa muka nepokolebljivom odlučnošću može preobraziti u sreću te osobe. Solidarnost sa osobama koje su izložene sličnim mukama uverljiva je i gotovo bezuslovna. Bliska osoba biva poistovećena sa nebeskim pojavama, a najlepši snovi su konvertibilni sa likom majke. Napokon, za poetiku o kojoj je reč naročito je karakteristična upečatljiva i efektna upotreba superlativa.

Kao da u savremenom svetu, iznad svega zasićenom nametljivošću, u kojem se superlativi poistovećuju s egoizmom i marketinškim zavođenjem, jedina opravdana upotreba superlativa biva rezervisana za slabe, isključene $i$ marginalizovane. Za razliku od nametljivog jezika reklame koji je ispunjen neprikladnim preterivanjima jer autoritarno želi da osvoji nečiji ukus i da podstakne želju, superlativi se kod osoba s ometenošću ne usmeravaju na isključivanje sličnog i konkurentnog. Naprotiv, oni su podstaknuti potrebom za zaobilaženjem prosečnog, uobičajenog, svakidašnjeg. Umesto da bude jednoznačan i zapovedan, njihov superlativ je nedvosmisleno romantičarski jer teži osvajanju nedoživljenog i prodoru u neiskušeno. Otuda je i lep san za osobu s ometenošću odviše običan, prosečan i nedovoljan. Tek »prelepi snovi imaju nadu« čime nam je sugerisano da tek značajna izmena odnosa između »poretka ovoga sveta i želja onih koji su mu podvrgnuti« (Rancière, 1981: 12) u slučaju osoba s ometenošću omogućava i osmišljava nadu. Svi uobičajeni atributi su beznadežni jer previše podsećaju na ličnu patnju, kao i na patnju svih onih u sličnoj situaciji: »Ti si moja 
tužna slika koja će uvek biti s tobom« (Vladisavljević, 2006: 16). Premda im pripisujemo hendikep, poetske tvorevine osoba s ometenošću itekako prepoznaju znak jednakosti između poretka u kojem žive i osujećivanja njihovih želja. Identitet sapatnika se poistovećuje sa vlastitom tužnom slikom, što znači da oni kojima pripisujemo intelektualnu ograničenost itekako pronicljivo uviđaju da je politički poredak u kojem žive takav da su identiteti isključenih lako zamenljivi. Štaviše, upravo ta politika im garantuje njihovu uzajamnu konvertibilnost jer ono što ih je isključilo nije njihova pojedinačnost niti posebnost, već pripadnost izvesnoj grupi.

Upečatljivi doživljaji nakon njihovih pozorišnih predstava, performansa $i$ literarnih zapisa iznova osvetljavaju Fukoovu tezu da političko uslovljava i najmanji bljesak istine (Fuko, 2006: 11). Istina koju pri tom otkrivamo nije svedena na neko konkretno saznanje, zahvaljujući kojem bismo bili u prilici da dopunimo ono što smo do sada saznali. Naprotiv, reč je o istini koja prosine onda kada nas estetsko iskustvo prisili da napustimo sebe, da se izmestimo i da se na trenutak sasvim približimo nekom drugom. Bljesak istine utoliko je osvetljavanje političkog i to u trenutku ukidanja postojećih distanci u neočekivanom, novostvorenom zbližavanju. Osvešćenje u političko posredstvom umetnosti postaje moguće tek kada nam, barem izvesno vreme, pođe za rukom da iskusimo i oblike izražavanja »koji ne nalaze svoje mesto u sistemu vidljivih koordinata u kojem se pojavljuju« (Rancière, 2004: 63).

Nije slučajno da su upravo »prizori bliskosti« bili zajednički naslov za proces u kojem su naši umetnici fotografskim aparatom beležili ono što im je značajno u njihovom vlastitom svetu. Uvereni smo da približavanje istini političkog posredstvom zbližavanja sa subjektivnošću koja je isprva bila daleka i nedostupna nije posledica usiljenog interpretativnog učitavanja. Ne radi se tek o slučajno proizvedenom utisku nego o intimnoj, ali više nego snažno proživljenoj potrebi samih članova grupe, koji odnos prema vremenu u kojem žive doživljavaju tako što ga »pritiskaju nadole«. Zemljina teža svakoga od nas »pritiska« za tlo, ali ukoliko tome pritisku i sami malo pomognemo može se desiti da ustuknu ili da se barem malo povuku pritisci »sa strane« koje osećamo u svom svakidašnjem životu. Ova neobična figura otpora rečito svedoči o želji osoba s ometenošću da suspenduju vladajuću logiku vremena i sveta u kojem živimo.

Neobično snažna i iskrena potreba za promenom metaforično je opisana kao menjanje života pod nogama, kao da se vlastitim trudom može postići da se tlo pod nama konačno pokrene u smeru u kojem mi želimo da se kreće. Jezik graničnih iskustava, govor u režimima aktuelne patnje i sna o sreći, ocrtava konture neprepoznate i nepriznate subjektivnosti. Da bismo to uverenje obrazložili pomenućemo da je jedna od posebnosti ove grupe to što raspolaže vlastitim spiritus movens-om, poetskom heroinom Natalijom Vladisavljević. U jednom razgovoru o pozorištu, na pitanje o tome šta misli da je važno u vezi sa glumačkim iskustvom, ona je odgovorila spartanskom jednostavnošću: »To što gledaš iznutra«. Pogled o kojem je reč ipak nije ni malo jednostavan i iziskuje ozbiljno promišljanje, dodatno interpretativno osvetljenje. 


\section{Unutrašnjost i priznanje}

Biti iznutra u pozorištu pre svega znači biti izvođač, a ne publika. Međutim, unutrašnjost Natalijinog pogleda tu ne završava, nego tek započinje. Glumačka situacija za nju takođe znači i dragocenu mogućnost otvaranja jedne drugačije unutrašnjosti. Prisustvo na sceni koje je osmišljeno i prilagođeno svakom pojedinom članu grupe, omogućava vanredno značajan događaj. Taj događaj bismo mogli da imenujemo samosvesno rađanje ličnosti. Zahvaljujući njemu Natalija, ali i svi ostali članovi grupe, mogu sebe iznova da osete, da osveste svoje postojanje u registru koji se značajno razlikuje od svakidašnjeg. Rečju, Natalija oseća dostojanstvo tek kada je prilici da učestvuje u distribuciji čulnosti koja je drugačija od uobičajene.

»Pogled iznutra«, o kojem govori Natalija, zapravo je sinonim za samosvest, za nov oblik samoodnosa koji predstavlja posledicu specifičnog vida priznanja koje dobijamo od drugih osoba. Važno je napomenuti da reč dostojanstvo nismo neosnovano učitali niti samovoljno pripisali zahvaljujući proizvoljnom fantaziranju o posebnostima njenog samoodnosa, nego smo je pronašli u vanredno lucidnim mislima: »Kad bi publika zatražila dostojanstvo od glumaca mogla bi sama da oceni kakvo treba da bude pozorište. A imitiranje života nije ni kulturno ni lepo« (Vladisavljević, 2006: 3).

Premda bi ovaj sažeti kroki u kojem je opisan trougao glumaca, publike i života mogao da podstakne opsežne refleksije o savremenom pozorištu, smatramo da glumci na koje Natalija aludira nisu glumci en général, nego su pripadnici njene vlastite grupe. Pozorište, uverava nas Natalija, nije onakvo kakvo bi trebalo da bude, jer je previše blisko našoj svakodnevici, zadovoljava se time da na sceni podražava život. A upravo to, prema njenom mišljenju, nije ni kulturno niti lepo. Ono što po svojoj prirodi nije lepo ne može takvo da postane ni na sceni, što znači da scensko prikazivanje nečega lepog pretpostavlja iskorak »izvan života«.

Podvig udruženja Per Art sastoji se u tome što svoj glumački ansambl, ali i svoju publiku u svakoj prilici vodi upravo tamo, izvan života. Taj iskorak za Nataliju i članove njene grupe postaje realnost onda kada svi zajedno prestanu da budu puki objekt posmatranja, kada više nisu poistovećeni sa svojom ometenošću, kada im scena dopušta da iskažu slobodu da se sami »pobrinu za sebe«, da artikulišu ono što im je blisko i ono do čega im je stalo.

U jednoj Natalijinoj belešci za buduće predstave možemo da pročitamo: »taj lik znači biti nešto što nije stvaran pogled u svetu kod ljudi« (Vladisavljević, 2014: 52). Negovati estetiku egzistencije znači upravo proizvoditi pogled koji u svakidašnjici nije ni stvaran ni zamisliv. Taj nestvarni pogled ipak nije mimo sveta. Odavno znamo da se na pozornici ništa ne dešava baš onako, kako se dešava u našem »bivstvovanju-u-svetu«. Možda je upravo zbog toga ona izabrana da pruži prostor onima od kojih se ne očekuje da se izraze, da stvori mogućnost da dođu do reči oni kojima je obično reč oduzeta. Pozorišna trupa Per Art nam omogućava 
da doživimo novu stvarnost jednog nestvarnog pogleda i novi život onoga što je do sada ostajalo izvan života.

Scena pruža autonomiju izražavanja, a njena tiha politika se krije u tajnama "pozorišne igre«. Prepuštenima igri, ne preostaje ništa drugo do da budu oni sami. Za razliku od demonstracije moći prema stvarima ili prema ljudima, igra nema nikakvu svrhu osim da bude odigrana. Daleko od svakog neposrednog efekta ili učinka, funkcija igre oslobađa gestove i činove koji oslovljavaju svoju publiku. Lično oslovljavanje ometenih u toj razmeni unosi značajnu novinu. Kada nam se oni obrate na sceni, značenja scenskog pokreta se preobražavaju u jedan moralni zahtev koji iz osnova dovodi u pitanje naša naviknuta ponašanja, uvrežene simpatije i antipatije, unosi nepoverenje u moralne rutine. Susret s drugošću ometenih za publiku postaje sinonim za iskorak iz egoističnog traženja sebe u drugima, a za same aktere na sceni šansa za nadmašivanje društvene separacije i ublažavanje pojedinačne traumatizovanosti.

Pozorišni gestovi osoba s ometenosti funkcionišu u skladu s mehanizmom oslovljavanja, a ne pukog poziva, oni privlače našu pažnju, menjaju našu percepciju. Ukratko, odlikuje ih moć moralne konverzije. Ukoliko je umetnička prezentacija ljudskog tela uvek ujedno predstavljala i »kreaciju kulturnih vrednosti« (Rössner, 2014: 9), onda se pozorišni život u kojem su glavni akteri osobe s ometenošću može zdušno podržati i ohrabriti zbog svih nas. Zbog njih, zato što im je scena jedna od retkih oaza na kojem mogu delati kao slobodne, samosvesne ličnosti. Zbog nas, zato što nas njihova sloboda budi, što omogućava da ne krijemo večito svoju slobodu, a ona je najčešće uspavana i ušuškana vladajućim moralnim rutinama. Ono što nas pomera $i$ vodi izvan tih rutina, što iz osnova dovodi u sumnju našu samouverenost i sigurnost $u$ odnosima prema drugom čoveku valja dočekati kao dragoceni dar, kao podsticaj i okidač koji pokreće slobodni čin. Da bismo svoju slobodu izvukli iz skrivenosti, potrebno je najpre da shvatimo da se ona izvorno sastoji u odgovoru na oslovljenost od slabijeg, odbačenog, marginalizovanog čoveka. Ako je tako, onda je njihovo pravo da igraju pozorišnu igru jednako našem pravu na našu slobodu. 


\section{WHO HAS THE RIGHT TO PLAY?}

\section{DISABILITY AND AESTHETICS OF EXISTENCE}

Summary: The article explores the relationship of disabled persons and theater, starting with the work of the Per-Art Association. In the first part, the author emphasizes that the mode of ontogeny of social solidarity with the disabled persons did not result in their greater representation in the arts but in a lesser one. After pointing out that the presence of disabled persons on the canvas has for centuries been reduced to a mechanisms thanks to which the everyday awareness of the "common" grew stronger, and rejected with ease all that deviated from the socially acceptable norms, the author analyzes the specificity of the inclusive gestures on the contemporary theater scene. Unlike the introduction of specific characters with disabilities into the conventional plays, the author points out that the everyday regime of care recognizes the disabled persons as objects, which must be taken care of by someone, while the conditions of the group artistic work enable them to tailor their own character so they need not rely upon the expectations and concepts of others. In the second part of the paper the author confronts the Foucault's term of aesthetics of existence with the theater work of the disabled persons. Appearing within a group, such persons enable a moral conversion, as the meaning of the scene movement transforms into an independent moral request. Meeting the foreign of the disabled persons, for the audience, becomes a synonym for a breakthrough in the egoistical search for the self in others, and for the actors themselves, marks a chance to break the social separation.

Keywords: aesthetics, existence, theater, disability

\section{NAVEDENA LITERATURA:}

Bass, A. (2006) Interpretation and Difference. The Strangeness of Care, Stanford University Press, Stanford.

Becker, U. (2015), Die Inklusionslüge. Behinderung im flexiblen Kapitalismus. Transcript, Bielefeld.

Buber, M. (1962) »Urdistanz und Beziehung«, u: Werke I. Schriften zur Philosophie, Kösel, München.

Fuko, M. (2002) Nenormalni, Svetovi, Novi Sad, prev. M. Kozić.

Fuko, M. (2006) Istorija seksualnosti I, Karpos, Loznica, prev. J. Stakić

Levinas, E. (1968) Totalité et infini. Essai sur l'extériorité, M. Nijhoff, La Haye.

Straus, J. N. (2011), Extraordinary Measures. Disability in Music, Oxford University Press, Oxford/New York.

Rancière, J. (1981) La nuit des prolétaires. Archives du rêve ouvrier, Fayard, Paris.

Rancière, J. (2004) The Politics of Aestetics, London/New York, tr. G. Rockhill.

Rösner, H.-U. (2014) Behindert sein - behindert werden. Texte zu einer dekonstruktuven Ethik behinderten Menschen, Transkript, Bielefeld.

van Rijn, M. (2011) »Die Gespielen der Infantin. Darstellungen kleinwüchsiger Menschen in der bildenden Kunst«, u: Disability History. Konstruktionen von Behinderung in der Geschichte, Transcript, Bielefeld, Hg. E. Bösl [et. al.].

Vladisavljević, N. (2006) Ovako ima smisla da živim ovako, [s.n.] Novi Sad.

Vladisavljević, N. (2014) Sunce na vagonu, Per Art, Novi Sad. 